\title{
Dětská neurologie: raketově se rozvíjející obor
}

\section{prof. MUDr. Pavel Kršek, Ph.D. - editor hlavního tématu, předseda Společnosti dětské neurologie ČLS JEP Klinika dětské neurologie 2. LF UK a FN Motol, Praha}

Vážené čtenářky, vážení čtenáři,

dětská neurologie patří v obecném povědomí k mladším lékařským oborům, přesto Ize její historii datovat již od konce 2. světové války. Česká škola se přitom do historie tohoto oboru zapsala nesmazatelným písmem. Již ve čtyřicátých letech zakládali akademik Kamil Henner v Praze a profesor Karel Popek v Brně samostatná dětská oddělení při větších neurologických klinikách. K rozvoji oboru významně přispěl profesor Ivan Lesný, který v r. 1957 založil Sekci dětské neurologie jako vůbec první vědeckou organizací dětské neurologie na světě. Od stejného roku u nás probíhají atestace z dětské neurologie, od r. 1958 pak i pravidelné každoroční konference (Dny dětské neurologie). V r. 1967 byla založena Subkatedra dětské neurologie při Katedře neurologie IPVZ, v r. 1971 vzniká první samostatné klinické pracoviště (Klinika dětské neurologie 2. LF UK a FN Motol), v r. 1994 pak samostatná Společnost dětské neurologie ČLS JEP. Z rady dalších osobností oboru můžeme jmenovat napríklad doktora Václava Vojtu, docenta Jana Dittricha, docenta Vladimíra Vlacha a primáře Jiřího Dolanského.

Dětská neurologie však v žádném prípadě není oborem nostalgicky hledícím do své minulosti. Držíte v rukách číslo Neurologie pro praxi, které približuje některé z aktuálních trendův diagnostice a léčbě vybraných skupin neurologických onemocnění u dětí. Věrím, že Vám nabídne poutavé a poučné čtení, které zcela vyvrátí donedávna tradovaný mýtus, že dětská neurologie je trochu smutným oborem, jelikož rada neurologických onemocnění je chronických, léčitelných obtižně či vưbec, u kterých často ani neznáme přesnou príčinu. Každé z následujících šesti sdělení presvědčivě ukazuje, jak revoluční pokrok se zcela konkrétním pozitivním dopadem na osudy dětských pacientů v různých oblastech našeho oboru v posledních letech nastal.

Vybrali jsme oblasti, u kterých je ohromný skok dopředu prímo hmatatelný: chirurgickou léčbu epilepsie, poznání genetických př́čin epilepsie, dědičné metabolické poruchy s neurologickou symptomatologií, autoimunitní onemocnění CNS, problematiku nervosvalových a neurokutánních onemocnění u dětí. Řada dalších sdělenís podobným obsahem by mohla následovat, namátkou problematika neurovývojových onemocnění, neuroonkologie, spánkových poruch v dětském věku, intenzivní péče v dětské neurologii či zcela nově se rozvíjející paliativní medicína u dětí se závažnými neurologickými chorobami. Doufáme, že vybraná témata probudí Váš zájem o bližší seznámení se s nejnovějšími trendy jak v těchto, tak dalších oblastech diagnostiky a léčby neurologických onemocnění u dětí.

Budeme-li číst následující sdělení pozorně, nemůže nám uniknout fakt, že tři témata se jimi táhnou jako červená nit; navzdory na první pohled značně odlišné povaze diskutovaných onemocnění.

1. Nově se objevujícínaděje pro dětsképacienty s dríve neléčitelnými či obtižně léčitelnými chorobami. Zejména moderní neurozobrazovací metody a molekulárně-genetická diagnostika nám umožňují odhalit přesnou prríčinu onemocnění, inovativní léčebné postupy pakjiž alespoň u části jednotek nabízí jejich kauzální ovlivnění. Reálně se tak mění napríklad prognóza dětí s farmakologicky nezvládnutelnou fokální epilepsií, závažnými autoimunitními chorobami, ale i geneticky podmíněnými onemocněními jako jsou svalové dystrofie, spinální muskulární atrofie či některé dědičné metabolické poruchy. Pacientům s kauzálně neléčitelným onemocněním pak nezrí́dka Ize alespoň ulevit od jejich potížía zlepšit tak kvalitu života.
2. Zásadní význam co nejčasnější diagnostiky a léčby pro prognózu pacientů. I když jsme svědky revolučního pokroku léčebných metod, zásadním předpokladem jejich úspěchu zůstává časná správná diagnostika. Ta nezřídka závisí na co nejčasnějším odeslání pacienta k vyšetření $\checkmark$ príslušném specializovaném centru. Současné číslo Neurologie pro praxi proto chápeme i jako nabídku těchto center kolegům z terénu: jsme připraveni se indikovaných prípadů ujmout; referujte je prosím raději dřive nežli později. Vyjma nejnovějších diagnostických a léčebných postupů (včetně možnosti zařazení některých prípadů do probíhajících klinických studií) nabízí uznaná centra rodinám nemocných dětí i další komplexní péči, včetně psychosociální podpory.

3. Naprostá nezbytnost široké mezioborové spolupráce prii péči o děti se závažnými neurologickými chorobami. S jen mírnou nadsázkou Ize rí́ci, že sám dětský neurolog již dnes nezmůže nic, nepracuje-li v jednom týmu s řadou dalších expertů - jen namátkou radiologů, genetiků, neurochirurgů, ortopedů, rehabilitačních lékařů, fyzioterapeutů, psychologů, logopedů, apod. Tato spolupráce dnes navíc nemůže zůstávat výhradně na národní úrovni; jsme svědky vzniku mezinárodních pracovních týmů, které na základě analýzy a sledování velkých skupin pacientů definují optimální diagnostické a léčebné standardy pro jednotlivá onemocnění. Můžeme s potěšením informovat, že některá klinická pracoviště dětské neurologie v ČR jsou součástí více takových týmů, např. v rámci Evropské referenční sítě pro vzácná onemocnění (ERN).

Věřím, milé kolegyně a milí kolegové, že Vás četba našich sdělení zaujme a bude motivovat k hlubšímu zájmu o dětskou neurologii; mladší kolegy pak třeba vybídne i ke specializaci v tomto oboru. 